\section{Natureza humana criada em laboratório: biologização e genetização do parentesco nas novas tecnologias reprodutivas}

\section{Human nature created in the laboratory: the biologization and genetization of kinship in new reproductive technologies}

\section{Naara Luna}

Professora do Seminário Teológico Batista do Sul do Brasil e da Faculdade de Educação da Baixada Fluminense, Universidade do Estado do Rio de Janeiro (UERJ) Av. Oswaldo Cruz 115/706 22250-060 Rio de Janeiro - RJ Brasil naara_luna@ig.com.br
LUNA, N.: Natureza humana criada em laboratório: biologização e genetização do parentesco nas novas tecnologias reprodutivas.

História, Ciências, Saúde - Manguinhos, v. 12 , n. 2, p. 395-417, maio-ago., 2005.

As novas tecnologias reprodutivas, também chamadas de 'reprodução assistida', são procedimentos que permitem a procriação sem a relação sexual, sendo as técnicas mais conhecidas a inseminação artificial e a fertilização in vitro (bebê de proveta). $\mathrm{O}$ acesso às técnicas também levanta a discussão sobre a genetização dos laços de parentesco, em contraste com as práticas de adoção ou procedimentos como a doação de gametas (óvulos e espermatozóides) e embriões. Com base em pesquisa etnográfica com usuárias e profissionais envolvidos em reprodução assistida, e em bibliografia específica, este trabalho visa discutir que concepções de natureza humana estão implicadas na biologização e na genetização do parentesco nas novas tecnologias reprodutivas.

PALAVRAS-CHAVE: novas tecnologias reprodutivas; parentesco; genetização; biologização.

LUNA, N.: Human nature created in the laboratory: the biologization and genetization of kinship in new reproductive technologies. História, Ciências, Saúde - Manguinhos, v. 12, n. 2, May-Aug., p. 395-417, 2005.

New reproductive technologies or assisted reproduction are procedures that make procreation possible without sexual relations, the most wellknown being artificial insemination and in vitro fertilization ('test-tube' babies). Use of these new techniques raises the issue of the genetization of kinship ties, in contrast with adoption or procedures involving the donation of gametes (eggs and sperms) and embryos. Based both on ethnographic research with users and professionals in assisted reproduction and also on bibliographic research, the article discusses the concepts of human nature implied in the biologization and genetization of kinship through these new reproductive technologies.

KEYWORDS: new reproductive technology; kinship; genetization; biologization. 
$\mathrm{E}$ ste artigo aborda as novas tecnologias reprodutivas, analisando as concepções de natureza humana implicadas na biologização e na genetização do parentesco. Constata-se na história a transformação de uma concepção de natureza humana oriunda da teologia cristã e da filosofia, integrante de um sistema moral (Pagels, 1989), para a noção de uma natureza humana intrínseca à dimensão biológica. Essa transformação teria origem na mudança de episteme ocorrida no Iluminismo, segundo a qual a Natureza deixa de ser o reflexo de valores maiores transcendentes e, laicizada, passa a ser a base física da realidade, objeto da ciência (Lenoble, 1990). A partir dessa nova concepção de Natureza se estabelece o ordenamento social (Laqueur, 1992). O conceito de natureza humana é englobado pela dimensão física ou biológica. A noção ocidental de parentesco baseia-se nos "fatos da vida": ter relação sexual, transmitir genes e dar à luz (Strathern, 1992, p. 5), fatos esses considerados naturais. A tentativa de gerar filhos mediante auxílio tecnológico na reprodução assistida é objeto aqui de investigação etnográfica. O discurso de usuárias e profissionais envolvidos com reprodução assistida ou com tratamento convencional de infertilidade revela diversas inquietações acerca desses procedimentos para geração de filhos. Pretende-se por meio da análise das representações dos processos de genetização do parentesco e biologização da identidade revelar a concepção de natureza humana implícita no discurso dos informantes.

Novas tecnologias reprodutivas ou técnicas de reprodução assistida são procedimentos da medicina de reprodução humana que substituem o ato sexual na concepção. As mais conhecidas são a inseminação artificial e a fertilização in vitro (bebê de proveta). Tais técnicas supõem a manipulação de pelo menos um gameta fora do corpo. Na inseminação artificial, em contexto medicalizado, faz-se estimulação ovariana leve, depois sêmen tratado é introduzido através do colo do útero no período fértil. Na fertilização in vitro, ou FIV, após um período de estimulação dos ovários com altas doses de medicamentos hormonais, coletam-se óvulos que, por sua vez, são unidos em laboratório com sêmen tratado. O embrião é transferido para o útero ou congelado. A ICSI (injeção intracitoplasmática de espermatozóide) ou micro-injeção é uma variedade de FIV em que se injeta apenas um único espermatozóide no óvulo, com indicação em casos severos de infertilidade masculina para os quais o recurso alternativo seria o sêmen de doador. FIV e ICSI possibilitam que o embrião formado com o óvulo de uma mulher seja transferido para o útero de outra. Caso o bebê seja destinado à gestante, trata-se de doação de óvulos. Se a mulher engravidar a fim de entregar o bebê a outra, é um exemplo de cessão de útero, popularmente conhecida como "barriga de aluguel". Em casos de infertilidade masculina, é possível também recorrer ao sêmen de doador. 
A constituição do parentesco é o ponto sob análise nas práticas que envolvem as novas tecnologias reprodutivas. Alguns aspectos básicos da simbólica de parentesco ocidental revelam os novos significados emergentes no contexto das tecnologias de procriação. Schneider (1968) identifica dois elementos básicos para a constituição da simbólica de parentesco americana: a relação como substância natural biogenética ou parentesco de sangue, e a relação como código de conduta. O primeiro caso corresponde à ordem da Natureza, em laços percebidos como inexoráveis, enquanto o segundo corresponde à ordem da Lei, com laços construídos socialmente pelos costumes e tradições, e considerados revogáveis. Ao estender as chances reprodutivas de casais inférteis, propiciando a concepção em laboratório e abrindo a possibilidade de doação de óvulos e de espermatozóides, ou de cessão de útero (barriga de aluguel), as novas tecnologias reprodutivas ampliam a possibilidade de constituição do parentesco como escolha e não como resultado de processos naturais inexoráveis. Além disso, a reprodução assistida permite que casais inférteis tenham filhos biológicos/genéticos, sem necessitar do recurso à adoção. Nesse sentido, essas técnicas permitem que se acentue o valor dos laços genéticos, o que constitui a genetização do parentesco, isto é, uma concepção de parentesco como as "ramificações biológicas da herança genética" (Strathern, 1999, p. 172).

O material sob análise se origina do trabalho de campo realizado em minha pesquisa para o doutorado no PPGAS/MN/UFRJ (Luna, 2004). Parte do material resulta de etnografia realizada no ano de 2002, no Instituto de Ginecologia da UFRJ, um serviço que oferece apenas tratamento convencional para infertilidade. Ali observei consultas e entrevistei com registro manuscrito pacientes do Ambulatório de Reprodução Humana nos dias designados para o atendimento de esterilidade. A entrevista versava sobre a experiência de infertilidade, relacionada à família e à adoção, pedindo também opiniões sobre práticas da reprodução assistida. Houve 63 entrevistas, seis das quais são citadas aqui. Outra parte do trabalho de campo consistiu em entrevistas gravadas com usuárias e profissionais de serviços de reprodução assistida em centros públicos e particulares entre os anos de 2000 e 2002 no Rio de Janeiro e em São Paulo. Também se procedeu à observação etnográfica em serviços públicos de reprodução assistida em São Paulo. As entrevistas com usuárias dos serviços de reprodução assistida aprofundam-se mais na experiência pessoal com as técnicas durante o tratamento e em questões éticas, enquanto para profissionais da área a ênfase está em aspectos técnicos e éticos. A maioria dos profissionais entrevistados trabalha no serviço público, e alguns médicos acumulam atividades em clínicas particulares. Dos 23 profissionais entrevistados, mencionam-se sete entrevistas. Das dezesseis 
usuárias da reprodução assistida entrevistadas, quatro são citadas. Na impossibilidade de examinar a totalidade desse material no presente artigo, optou-se por enfocar os trechos em que a temática abordada apareceu de forma mais explícita, iluminando o presente debate. A presença no VI Congresso Brasileiro de Reprodução Assistida, em setembro de 2002, complementa esse material. A Resolução 1358/92 do Conselho Federal de Medicina, que estabelece normas para a reprodução assistida, serve de contraponto à análise.

\section{A genetização do parentesco}

O processo de genetização do parentesco é perceptível no recurso a exames de DNA para provar a existência de laços de parentesco e no desenvolvimento de tecnologias da procriação (Franklin, 1999). Ingold (1991, p. 361) afirma que a noção de relacionamento genético é absurda, pois o parentesco genético se refere às afinidades de atributo (attributional affinities) que estão presentes no indivíduo em virtude de sua constituição endógena previamente a sua entrada em qualquer relação. A genética diria respeito a coeficientes quantitativos de aparentamento (relatedness), e não à dinâmica de relacionamento. ${ }^{1} \mathrm{O}$ parentesco genético é um parentesco cortado do contexto dos relacionamentos e atribuído em termos de uma propriedade comum dos indivíduos considerados entes separados e isolados. ${ }^{2}$ Essa observação de Ingold é congruente com um aspecto central dos modelos ocidentais de parentesco, na medida em que não se percebe o nascimento de uma criança ocorrendo em um campo de relacionamentos, mas como o surgimento de uma pessoa individual com necessidade posterior de relacionamentos (Strathern, 1995a). Quero questionar essa afirmação de Ingold de que o aparentamento genético é não-relacional, com as pessoas aparecendo tal qual mônadas. Strathern (1995b, p. 357) lembra que genética diz respeito tanto à constelação singular de características que constitui indivíduos como a laços de sangue e ancestrais. Ao contrário da afirmativa de que o aparentamento genético não se refere à dinâmica de relacionamento, no caso de laços de sangue, os relacionamentos são evidentes como laços entre pessoas específicas; além disso, esses relacionamentos contribuem com os componentes da constelação de características que constitui a pessoa individual.

A procura de exames de DNA para comprovação da paternidade evidenciaria de que modo a "constelação de características" ou os coeficientes quantitativos de aparentamento dizem respeito aos relacionamentos entre as pessoas. Leite (2000), contrapondo a "verdade biológica" e a "verdade afetiva" da paternidade, questiona se o estabelecimento de uma "verdade legal" por meio do exame de DNA contribui para a determinação da paternidade responsável 
ou apenas se limita à indicação do genitor. Fonseca (2002) mostra apropriação dos exames de DNA por mulheres das camadas populares na Grande Porto Alegre com motivações diversas. As motivações são relacionais, desde as mais invocadas, tais como garantir a contribuição financeira dos pais para a criação dos filhos e a acusação de "golpe do baú", até a tentativa de reatar a relação com o companheiro, e o desejo dos filhos de conhecer sua origem e estabelecer um relacionamento com os pais. Fonseca (2003) descreve o interesse masculino nos testes de DNA para tirar dúvidas sobre a paternidade e em casos em que o homem rompeu a relação estável com a companheira, tentando desfazer concomitantemente os laços de filiação e os conjugais. A ditadura da "verdade biológica" do DNA não vale para os casos que implicariam a destituição da paternidade no registro de nascimento sem a atribuição de outro pai, visando assim ao resguardo da criança. A fundamentação do parentesco na genética é então deixada de lado, caso implique revogar um relacionamento sem constituir outro. Portanto, a genetização do parentesco não é absoluta, mas contextual. Os resultados dos estudos de Fonseca $(2002 ; 2003)$ demonstram que, se o parentesco genético pode constituir mônadas como afirma Ingold, nas reivindicações quanto aos exames de DNA as pessoas se constituem como seres geneticamente relacionados.

Geneticistas, ao escrever sobre história da ciência, acentuam os erros e as descontinuidades entre o modelo "ultrapassado e errôneo" de hereditariedade pelo sangue e o da ciência genética que corresponderia à representação verdadeira de fatos biológicos (cf. Dunn \& Dobzhansky, 1956). Entre meus informantes, não encontrei descontinuidade, mas superposição das noções de sangue e DNA, conforme se explicita na afirmação desta entrevistada: “Eu quero ter o filho ali que é meu, que tenha uma parte de mim, tem meu sangue, tem meu eu ali, tem meus DNAs" (usuária, 42 anos, serviço privado de reprodução assistida). A associação de constituição genética com sangue nem sempre coincidiu. Outra informante do Instituto de Ginecologia (35 anos) teve reação semelhante quanto à doação de óvulos: "Vai ser meu filho? Do meu sangue?". Expliquei que o óvulo que contém o DNA seria de outra. Quando perguntei se aceitaria ser mãe por intermédio de uma barriga de aluguel, ela foi firme: "Não, porque não ia ser do meu sangue, eu ia estar só emprestando o meu óvulo e o do meu marido" (sic).

Esse tipo de comentário surge quando se discute adoção ou doação de gametas. Essa informante recusa a possibilidade de receber doação de óvulos, porque o filho não seria dela por parte genética ou sangue: "Eu sei que é filho do meu marido, mas não é meu filho. Só ia ser pela... nem pela parte genética, porque sangue, nada ia constar meu" (usuária, serviço público de reprodução assistida, 29 anos). "Sangue" e "parte genética" são expressos de forma equivalente. $\mathrm{O}$ "sangue" é o veículo de transmissão de características de 
pais para filhos, sendo uma "herança de família": "O sangue é... ter aquela herança de família ... Aqui em São Paulo, eu não tenho coragem de adotar uma criança, porque eu não sei daonde que veio, quem é o pai. E geralmente mais é filho de traficante" (usuária, serviço público de reprodução assistida, 36 anos).

A observação sobre a herança de características sociais poderia ser compreendida ou a partir da antiga configuração físico-moral de valores (Duarte, 1986), como degeneração (cf. Carrara, 1996), ou a partir da moderna Sociobiologia (cf. Sahlins, 1976). Um dos médicos usou argumentos calcados no determinismo genético para mostrar a reprodução assistida como opção preferível à adoção, assumindo uma postura eugênica.

Eu, antes da fertilização in vitro indicava muita fertilização, a adoção. E na minha vivência desses 45 anos, eu tive um prognóstico muito sombrio dos casais que fizeram a adoção. Então, eu só vou lhe dizer que $30 \%$ dos casais que eu acompanho que adotaram, os filhos são drogados. Apesar... Veja, filhos adotivos. Em 30\% deles, o QI é muito baixo, não acompanham a escola. Então hoje eu já contra-indico formalmente. (Médico, serviço público e privado, 69 anos.)

A existência de opção médica para gerar filhos permite a "contraindicação" (sic) do processo social de obtê-los mediante a adoção.

\section{O parentesco de sangue como idioma de pertencimento}

O motivo mais alegado pelas usuárias que procuram tratamento de infertilidade é o desejo de ter o filho "meu mesmo", "do meu sangue". Os laços de sangue são símbolos de pertencimento entre pessoas, das relações de filiação. Entre as categorias definidoras do domínio cultural do parentesco no Brasil, o sangue é "substância transmissora de qualidades físicas e morais, formando o corpo e o caráter" (Abreu Filho, 1982, p. 98 ss). O sangue articula a ordem da Natureza com a ordem da Cultura, transmitindo mais do que genes. A pessoa nasce mais do que um simples corpo natural, já surgindo "moralmente constituída, representante de uma família, uma tradição". Embora haja a possibilidade de interpretar os laços de sangue na qualidade de conexão biogenética (Schneider, 1968), com referência às características físicas da pessoa, as informantes que manifestaram receio quanto à adoção mencionaram com maior freqüência traços de temperamento e sociais. Assim, na simbólica de parentesco aqui identificada sangue abrange características físicas e sociais das pessoas.

As preocupações quanto ao recurso à reprodução assistida relacionam-se à formação do parentesco. Questiona-se a possibilidade de óvulo e espermatozóide virem de terceiros, introduzindo caracte- 
rísticas de desconhecidos na família: "Quando o óvulo e o espermatozóide é [sic] do casal, as características da criança vão ser da família do casal. Agora, vem de outro, vai ser [sic] as características de uma outra família que você não sabe como é" (usuária, serviço privado de reprodução assistida, 32 anos).

Quando a reprodução assistida exige material germinativo que envolve outras pessoas além do casal, algumas condicionaram a aceitação da técnica à participação de parentes. Uma informante do Instituto de Ginecologia da UFRJ (39 anos) diz que aceitaria doação de óvulos "só se fosse das irmãs, de outra não ... É porque está tudo em família". A psicóloga de um serviço público (38 anos) conta de uma usuária que trouxe sua irmã gêmea idêntica para fornecer os óvulos, alegrando-se pelo fato de a doadora não ter sido aceita, o que poderia "causar problemas emocionais". A embriologista de uma clínica privada (40 anos) conta que uma postulante a receber óvulos insistia para usar os gametas da irmã, da filha, da mãe. A profissional tentou convencer a postulante da necessidade do anonimato da doadora, permitindo que a receptora mantivesse segredo sobre a doação se assim o desejasse, pois em conflitos familiares uma irmã doadora poderia revelar à criança ser esta filha dela (irmã da mãe) com o pai. As posturas antagônicas das usuárias e de ambas as profissionais levantam as questões principais a respeito da doação de óvulos entre irmãs. A primeira opinião a vê favoravelmente porque há proximidade entre irmãs, tanto por compartilharem a mesma substância como pela colaboração pressuposta entre elas. Já a segunda posição vê na doação uma ameaça aos relacionamentos existentes (Edwards, 1999, p. 73 ss).

Quando perguntei a uma usuária do Instituto de Ginecologia sobre a possibilidade de solicitar a outra mulher que fosse a mãe substituta na gestação da criança, ela afirmou: "Só se fosse minha irmã. Na minha irmã, eu confio" (33 anos). A expectativa é de que uma parente tão próxima não se recuse a entregar a criança ao casal. Outra usuária de 24 anos diz que recorreria às suas tias para gerarem o filho dela na barriga, porém duvida de que elas fossem lhe entregar o bebê, pois adoram crianças. Ambas, sem saber, estavam agindo consoante as regras do Conselho Federal de Medicina - a única regulamentação sobre a reprodução assistida neste país até o momento - que permite a "doação temporária de útero" apenas entre parentes próximas da mãe genética e sem caráter comercial. Há uma convergência entre a Resolução 1358/92 do CFM e as posturas das informantes que pressupõem a colaboração desprendida entre parentes próximas, conforme constatado por Edwards (1999). Na perspectiva da colaboração em família, é difícil explicar para uma interessada por que o CFM julga lícito irmãs serem gestantes substitutas e por que não é permitido que sejam doadoras de óvulos. A regra do anonimato dos doadores impede tal colaboração entre 
irmãs para a doação de gametas, sugerida por um dos médicos entrevistados e também aventada por outros na Inglaterra (Price, 1999).

Ao impor o anonimato dos doadores de gametas, mas não o da gestante substituta, essas regras hierarquizam os tipos de parentesco, priorizando como verdadeiro o parentesco genético. Pode estar em jogo a impossibilidade de esconder a gravidez substituta, situação distinta da doação de gametas. A embriologista citada considera que, no caso de uma mulher que doe os óvulos para sua irmã engravidar com o embrião formado com o sêmen do marido da irmã, os fornecedores de gametas seriam os pais verdadeiros. Por que não pensar na gestante substituta que recebeu o embrião de sua irmã e do respectivo marido como a mãe verdadeira? Uma gestante substituta e um doador de gametas teriam como ponto comum o fato de cederem material reprodutivo sem intenção de procriação para si. Por que a cessão do útero é vista de forma diferente da doação de gametas, de modo que o primeiro processo deva ocorrer necessariamente com parentes da mãe intencional fornecedora dos gametas, e o segundo processo exige o anonimato do doador na regra brasileira? A concepção de que o laço genético constitui o parentesco verdadeiro informa essas diferenças de critério.

Um dos projetos de lei regulamentando a reprodução assistida em tramitação no Congresso Nacional estabelece que os gametas de um doador não sejam destinados a mulheres diferentes (Diniz, 2003). Isso evita o casamento consangüíneo inadvertido ou incesto das pessoas concebidas com os gametas desse doador. Além disso, se o material de um doador for utilizado mais de uma vez, está implicado que as crianças nascidas teriam os mesmos fornecedores de gametas em sua concepção, o que resultaria em relações consangüíneas entre os filhos do mesmo casal. Note-se que, no contexto inglês, o anonimato no tocante à doação de óvulos pode ter sido recomendado, mas nem sempre foi obrigatório, registrando-se, pelo menos na década de 1980, casos de doação entre irmãs e de tentativas de doação de filha para mãe, o que seria tolerado em caso de grupos étnicos minoritários. ${ }^{3} \mathrm{No}$ exemplo inglês reportado, a mulher estaria satisfeita em receber óvulos da irmã por preservar a linhagem de sangue (bloodline) da família (Edwards, 1999). Um médico entrevistado (serviço público e privado, 69 anos) que sugeriu a doação entre irmãs afirmou a necessidade de fazer "uma investigação a fundo" no caso de uma doadora anônima. Ele comenta que não se admite fazer com doadora que "você não sabe de onde é que vem", em contraste com recurso a bancos de sêmen, pois "já sabe os cuidados que eles têm na preservação desse sêmen". Dificilmente se questiona a necessidade de anonimato do doador de sêmen para o casal receptor, exceto com o objetivo de revelar a identidade quando a pessoa gerada chega à maioridade. ${ }^{4}$ Seria 
uma questão de oferta e demanda: as regras do anonimato mais flexíveis para a doação de óvulos, um bem escasso, ou representações de gênero estão em jogo? A despeito da "continuidade genética" da família, não se pensa em solicitar doação de sêmen entre irmãos, o que sugeriria infidelidade, ferindo a "honra masculina" (Aragão, 1983) ou causando conflitos ao incidir na competitividade entre homens para a reprodução (Edwards, 1999). ${ }^{5}$

\section{Genetização do parentesco e escolha nas NTR}

Para se contrapor à representação que identifica a essência do parentesco nos laços naturais ou biológicos, invoca-se a intenção do casal de fazer o filho na defesa de práticas que envolvam o uso material reprodutivo de terceiros. A intenção é definidora da parentalidade: o direito coloca desse modo a decisão conjunta do casal no consentimento informado quanto ao recurso à doação de gametas, de embriões ou cessão de útero (Leite, 1995). Esse tipo de atitude conjuga idéias tradicionais de parentesco fundado na procriação e na natureza com a dimensão de escolha dos envolvidos, dimensão característica da ideologia individualista moderna (Strathern, 1992). Analisando o recurso à inseminação com doador por parte de casais de lésbicas, Hayden (1995) afirma que o poder gerador é atribuído à "co-mãe" (coparent) ao participar da decisão conjunta de gerar e criar o filho. Ela relata casos de inseminação caseira em geral com sêmen de amigo homossexual, ou em contexto medicalizado com doador anônimo. Há tanto situações em que o projeto de procriação envolve a escolha de pessoa amiga para participar, ou seja, a recusa do anonimato, como de um doador anônimo cujo papel masculino ficaria minimizado pela falta de contato físico. Fui informada de um exemplo brasileiro que retrata bem essa relação de coparentalidade do casal lésbico. ${ }^{6}$ Um casal de mulheres planejava ter um filho e comprou sêmen de bancos do exterior pela Internet. Pouco depois a dupla se separou. A que adquiriu o sêmen constituiu outra união e sugeriu à nova companheira que tivessem o filho, a primeira sendo inseminada. A companheira atual aceitou a proposta, impondo como condição a aquisição da amostra de sêmen de outro doador, pois o já comprado era "o filho da outra". O casal já tem um filho, e agora a companheira que não engravidou pretende recorrer ao sêmen do mesmo doador para que os filhos do casal sejam irmãos consangüíneos. Mais uma vez tem-se aqui a dimensão da escolha, pois, quando o casal decide conjuntamente ter filhos, ambas são mães, e a dimensão da natureza, quando se quer reforçar a união da família por meio da consangüinidade dos filhos.

A dimensão da escolha fica tolhida pelas regras do CFM que impõem o anonimato dos doadores e a relação de parentesco entre a mãe genética e a que cede o útero para a gestação. Uma médica 
(50 anos, clínica privada) relata ter negado a solicitação de um casal de lésbicas: "elas queriam que uma cedesse os óvulos e esses óvulos seriam inseminados com o espermatozóide de um doador e os embriões fossem colocados na outra". ${ }^{7}$ O pedido não se enquadrava na doação de óvulos, que teria que ser anônima, nem seria aceito como cessão temporária de útero segundo as regras do CFM, pois a pretendente a receber o embrião "não teria nada a ver com aquela criança e ela não teria vínculo nenhum biológico, qualquer que fosse, com a doadora do óvulo". Essa justificativa não se baseia simplesmente na idéia de "procriação natural" (mulheres juntas não são um par procriativo), mas está relacionada com a interpretação da Resolução 1358/92 do CFM que estabelece regras sobre o que é aceitável na intervenção médica para a reprodução assistida. O casal de mulheres foi impedido de gerar um filho por meio da reprodução assistida de uma forma que ambas tivessem alguma comunhão de substância com a criança, seja pela dotação genética, seja pela gravidez. Do mesmo modo que no modelo de procriação sem assistência médica, o casal de mulheres era o par que escolheu uma à outra para uma relação amorosa e geração de filhos. O projeto de filhos dotados de alguma relação biológica com o casal homossexual suscita a busca pela reprodução assistida. As regras da reprodução assistida têm o casal heterossexual como modelo, o qual jamais seria impedido de alcançar a gravidez por meio da transferência do gameta de um membro do par para o útero do outro membro. As regras impondo o anonimato de doadores - indesejável para o casal em questão apenas no tocante aos óvulos - foram elaboradas para outro contexto que não prevê essa apropriação das técnicas com outra intenção que não a do tratamento da infertilidade. De fato, a solicitação pelo casal de maternidade conjunta através da contribuição do óvulo de uma e da gestação da outra se relaciona também a "fatos naturais" do parentesco ocidental, isto é, a transmissão genética e o parto (Strathern, 1992, p. 5), não se enquadrando nas definições de doação de gametas nem de gestação substituta. As regras do CFM se pretendem fundadas no modelo da natureza, enquanto se espera que as tecnologias de procriação aperfeiçoem a natureza desde que se mantenham fiéis a seus parâmetros (Hirsch, 1999). É explícita a tensão no modelo subjacente a tais regras, ou seja, reprodução "natural" heterossexual por um lado, e possibilidade de fundar a reprodução em escolhas por outro. Há tensão entre a afirmação da natureza como a ordem moral e a ordem social que se impõe sobre a natureza por meio de escolha, desejo, direito. Trata-se da polaridade entre determinação e vontade (Salem, 1995).

$\mathrm{O}$ aspecto social do parentesco é relevante quando se pensa em legalizar a relação de filiação. Em palestra, um médico descreve os avanços das tecnologias de concepção e comenta sobre o trans- 
plante de citoplasma. ${ }^{8}$ Essa técnica é usada para "rejuvenescer" gametas injetando citoplasma de óvulos de mulheres jovens em óvulos das mais maduras. Nesse transplante, mitocôndrias, organelas que contêm um tipo de DNA, também são transferidas. Isso implica a presença de DNA mitocondrial da doadora no embrião formado, além do DNA dos pais intencionais fornecedores de gametas. O médico diz alertar a paciente sobre a possibilidade da presença de uma porção ínfima desse DNA no óvulo a ser fecundado. Estava implícita a interpretação de que a contribuição genética de duas mulheres implicaria a existência de duas mães genéticas, posição levantada na imprensa (Luna, 2002a). Talvez por isso o médico observe em seguida: "São os advogados que definem quem é filho de quem", subordinando um parentesco dito natural à determinação social.

Mesmo no tocante à genética, há uma hierarquização de características conforme a origem nuclear (no genoma) ou mitocondrial do DNA, conforme se percebe no comentário sobre as conseqüências da transferência de citoplasma: “O que vai determinar a parte de genoma mesmo, inclusive até doenças e características físicas ... é a parte nuclear. A parte do DNA mitocondrial tem mais a ver ... com a questão de metabolismo ... do que com o que você transmite realmente para sua descendência" (embriologista, serviço público, 29 anos, sexo feminino).

Nesse exemplo um dado biológico - a transmissão de característica genética - pode ser considerado não relevante. Se existe uma crença em uma base natural da realidade, certos aspectos da 'natureza' contam mais do que outros. Com base na irrelevância do DNA mitocondrial, os especialistas que usam a técnica de transferência de citoplasma afirmam a licitude da prática.

Um exemplo da definição social do parentesco está nos contratos para gestação substituta. Uma das médicas entrevistadas (50 anos, clínica privada) apresentou uma comunicação no Congresso Brasileiro de Reprodução Humana em 2002 sobre a experiência em sua clínica de fertilidade com o "primeiro registro legal brasileiro" de criança nascida através de cessão temporária de útero (barriga de aluguel) em que a criança foi registrada com o nome dos "pais biológicos", isto é, os pais intencionais genéticos, fornecedores dos gametas. ${ }^{9}$ A Resolução 1358/92 do CFM estabelece que a gestação de substituição ou doação temporária de útero é um recurso a ser usado, "desde que exista um problema médico que impeça ou contra-indique a gestação na doadora genética". Além de impor que a prática não tenha "caráter lucrativo ou comercial", a regra define quem poderia ser a gestante substituta:

VII - 1 - As doadoras temporárias do útero devem pertencer à família da doadora genética, num parentesco até o segundo grau, 
sendo os demais casos sujeitos à autorização do Conselho Regional de Medicina.

A interpretação dessa regra tem permitido que irmã, mãe, filha, prima, tia e sobrinha cedam o útero para a mãe genética. A imprensa reportou casos entre irmãs e entre tia e sobrinha no Brasil (Luna, 2002b). No caso citado pela médica, a mãe genética recorreu à irmã de seu marido (sua cunhada) para a gestação substituta. Para o registro da criança, a mãe genética levou o protocolo de consentimento informado de ambos os casais (os 'pais genéticos' e a cunhada e seu marido) e a declaração de nascido vivo da maternidade, fazendo a petição na corregedoria do Juizado da Infância e da Adolescência a fim de expedir a certidão de nascimento com o nome dos pais genéticos diretamente por esse juiz e não pelo cartório. A médica conta como uma conquista o fato de que a "justiça brasileira reconheça que a criança era filha dos pais biológicos". Trata-se de um rito de instituição com o poder de "agir sobre o real ao agir sobre a representação do real" (Bourdieu, 1996, p. 101). O rito faz reconhecer como legítima e legal a relação de parentalidade dos fornecedores dos gametas em detrimento da declaração de registro de nascido vivo da maternidade, onde constavam os nomes da gestante e de seu marido, conforme a tradição jurídica de que a maternidade se estabelece pelo parto, com a presunção de paternidade do marido (Leite, 1995). A solução jurídica na França e na Inglaterra é a entrega da criança pela gestante substituta para adoção pelo casal que a planejou (Leite, 1995). ${ }^{10}$ Perguntei à médica se não houve problema pelo fato de a gestante substituta não ser parente genética da mãe. Segundo os assessores jurídicos da clínica, não havia problema, porque a regra do CFM estabelecia "parentesco de primeiro ou segundo grau" da mãe genética, e "a lei brasileira não especifica no parentesco o sangüíneo e o afim" ${ }^{11} \mathrm{O}$ casal não quis a via da adoção, nem usar subterfúgios como declarar a criança nascida em casa e apresentar testemunhas; pelo contrário, pediu que o processo fosse legal. ${ }^{12}$

Muitos consideram a contribuição com gametas, os portadores da constituição genética, a base da parentalidade, o que fundamentaria a recusa da doação: "Doaria o meu filho? Não doaria. Doaria a minha carga genética para alguém?", conforme disse uma enfermeira graduada de serviço público de reprodução assistida (40 anos), equiparando óvulo e "carga genética" a um filho. Esse tipo de raciocínio é central no debate sobre a doação de gametas. No Direito, considera-se que o doador de gametas abriu mão irreversivelmente de sua constituição genética em favor de outros (Leite, 1995). O diferente tipo de corporificação dos gametas acarreta conseqüências distintas para homens e mulheres doadores, pois, $\mathrm{o}$ sêmen doado pode ser congelado, o que permite o afastamento do 
doador em relação aos receptores tanto geográfica quanto temporalmente (Tamanini, 2003). Isso não é possível no caso da doação de óvulos, pois os ciclos da doadora e da receptora têm que ser sincronizados, ocorrendo ao mesmo tempo e no espaço físico da mesma instituição. Em caso de doação de óvulos, além do anonimato, evita-se contar para a doadora se a receptora conseguiu engravidar. Essa curiosidade surge em casos de doação compartilhada de óvulos, quando a receptora paga o tratamento e medicações da doadora e recebe metade dos óvulos, desde que a doadora tenha produzido no mínimo sete óvulos. ${ }^{13}$ A doação compartilhada é um assunto polêmico dada a assimetria entre a doadora e a receptora, envolvendo um fluxo de gametas femininos por um lado, em troca do custeio de medicamentos e tratamento, de outro, o que sugere relações de exploração (cf. Corrêa, 2000).

No VI Congresso Brasileiro de Reprodução Assistida, dois especialistas travaram uma discussão sobre necessidade de recomendar aos casais receptores que contassem aos filhos sua geração mediante gametas doados. O médico que sugeria revelar a doação previa que no futuro próximo "o DNA estará no RG das pessoas, e a pessoa saberá que não é filha dos pais", com expectativa de genetização da identidade legal. $\mathrm{O}$ outro especialista contestou a posição: "Ela pariu, ela amamentou e vai dizer que ela não é mãe?". Ele continuou contrastando a situação com a adoção: "A mulher que recebeu o bebê, recebe um produto pronto e vai transformar esse bebê em cidadão. No caso da doação de óvulos, ela recebe oito células, esse bebê deve tudo a ela. Ela vai enjoar, vai sentir o bebê dentro dela". Esse debate envolve dois referenciais biológicos de maternidade e parentesco: a contribuição genética e a gestação. É necessário então explicitar "o que é biológico na maternidade biológica" (Strathern, 1998, p. 195). A definição da maternidade pelo parto favoreceria uma mulher que recorresse à doação de óvulos, enquanto um teste de DNA comprovaria a maternidade da mãe intencional fornecedora do óvulo, em detrimento da gestante. Com as novas tecnologias reprodutivas fragmenta-se a unidade do papel fisiológico materno na geração (Strathern, 1992): uma mulher pode fornecer o gameta, a outra ceder o útero, uma terceira amamentar e a última ser a mãe social (criar).${ }^{14}$ As convenções sociais vão definir a mãe verdadeira (Strathern, 1991). Outro aspecto desse debate refere-se à identidade de pessoa traduzida em termos físicos: oito células (um embrião) ou o DNA?

\section{Biologização da identidade}

Na doação de gametas, a compatibilização das características físicas do doador com as do receptor é um imperativo. A Resolução 1358/92 do CFM recomenda a máxima semelhança fenotípica e 
imunológica, uma responsabilidade do serviço. Uma usuária do Instituto de Ginecologia da UFRJ (37 anos) disse que aceitaria doação de óvulos de uma pessoa parecida fisicamente com ela, para que o filho não ficasse diferente dos pais. A enfermeira de um serviço público de reprodução (40 anos) encarregada de organizar o projeto de um banco de sêmen perguntou-me se como antropóloga eu poderia dar algumas 'dicas' sobre a caracterização do fenótipo dos doadores. Sua dificuldade estava em classificar os "nordestinos". Outra informante do Instituto de Ginecologia (29 anos) candidatou-se a doadora de óvulos em uma clínica particular. ${ }^{15}$ Respondeu a uma bateria de questões sobre sua saúde e ouviu da profissional encarregada da seleção que sua aparência era excelente (morena clara com cabelos castanhos lisos e olhos castanhos). A profissional desinteressou-se da doação quando constataram que a mãe da candidata era negra. Contei esse fato à psicóloga de outro serviço público de reprodução humana (38 anos) que achou perfeitamente justificável a exclusão da candidata, pois as pessoas querem ter filhos parecidos com elas, mesmo recorrendo à doação de gametas. ${ }^{16}$ Salem (1995) designa essa prática de compatibilizar características físicas dos doadores e dos receptores de "manipulação social das origens genéticas", em que se tenta mimetizar o parentesco biológico convencional.

A legitimidade das relações de parentesco engendradas pelas tecnologias reprodutivas pressupõe a proximidade com as relações de parentesco de origem genética. A falta de semelhança entre a criança concebida por meio de doação de gametas e os seus pais pode revelar o segredo da doação, com o risco de se considerar a filiação ilegítima. Uma embriologista descreve a necessidade de compatibilizar características físicas nem sempre identificáveis visualmente:

Casar desde tipo sangüíneo, até toda a sorologia dessa paciente, tudo ... Casar o ciclo, casar fenótipo, cor de olhos, cor de cabelos, tipo sangüíneo, porque é uma opção da paciente não querer contar para criança depois se ela conseguir a gravidez qual é o... quem é a mãe, quem é a doadora, ou coisas desse tipo. (Embriologista, clínica privada, 40 anos.)

Costa (2003) observa que semelhança fenotípica substitui simbolicamente a transmissão de genes. A autora atribui justificativas médicas para o critério de semelhança imunológica, em contraste com a semelhança 'fenotípica' que visaria evitar problemas familiares no tocante à não-mistura de raças. As justificativas dos profissionais demonstram que a busca de semelhança imunológica se dá também para se evitar trair o segredo da doação para os filhos. Uma médica entrevistada fala da importância da compatibilidade do tipo 
sangüíneo entre doadores e receptores, por causa dos conteúdos apresentados à criança na escola:

O tipo sangüíneo é essencial ... qualquer criança que chega na escola que aprende o tipo sangüíneo genético, ela chega em casa e ela pergunta: "pai, qual é o seu? Mãe, qual é o seu?", porque ela vai cruzar. É a prática que ela aprendeu na escola. E a maioria desses casais não fala em doação. (Médica, clínica privada, 50 anos.)

Esse exemplo mostra que se divulga a biologização da identidade e do parentesco por meio dos programas escolares de ciências. A escolha de características dos doadores vai além da compatibilidade de aparência física, com catálogos de doadores de sêmen que incluem vários atributos "sociais" que permitiriam aproximar os receptores dos doadores.

Dr. J - Existe [sic] ... características de personalidade ... e a religião é muito mais colocada para ter uma idéia de personalidade do doador. Mas não que isso obrigatoriamente seja uma característica que os casais dêem muita importância não. Até existe listada. Cor de olhos, cor de cabelos, cor de pele, musculatura, tal, religião, raça, existe isso lá ... Profissão, hobby. (Médico, serviço privado, 47 anos.)

A descrição nos catálogos de características do doador, não apenas físicas, mas sociais, naturaliza tais traços (Cf. Cussins, 1998).

\section{Natureza como valor}

É necessário distinguir representações da biologia e representações da ordem natural à qual se atribui um valor moral. Enquanto representação, a Natureza é tanto a biologia em si, como um referente do que é bom para continuar a existência, uma ordem moral representando um modelo ideal de realidade. À Natureza se contrapõe a tecnologia, um resultado do desenvolvimento cultural humano.

A seleção natural é a representação de um processo biológico evocado diversas vezes por profissionais entrevistados. Nessas declarações, em particular de médicos, a seleção natural é um processo da Natureza considerado benéfico. A interferência nesse processo pelas tecnologias de procriação é motivo de preocupação quanto a riscos desconhecidos. Homens inférteis por causa de anormalidades cromossômicas, recorrendo a ICSI, podem gerar filhos com os mesmos problemas, em um processo que seria barrado pela seleção natural não fosse a técnica. ${ }^{17}$ Um dos médicos entrevistados critica a técnica de transferência de citoplasma para melhorar a qualidade dos óvu- 
los, porque geraria a presença de DNA mitocondrial de duas origens diferentes. Isso jamais ocorreria na fertilização, porque as mitocôndrias do espermatozóide não entram no óvulo, e mesmo que sejam introduzidas com o espermatozóide inteiro na ICSI, elas são eliminadas:

Quando o DNA que vem é feminino, parece que a natureza não consegue degenerar esse DNA mitocondrial da doadora, e acontece na criança uma heteroplasmia que ... a natureza, até aquele ponto, mesmo com a ICSI, tentou brigar contra. (Médico, serviço privado de reprodução assistida, 47 anos.)

O informante considera esse resultado uma "situação totalmente diferente, anômala". Franklin (1999, p. 160) observa que a natureza é redesenhada (redesigned) com as novas tecnologias reprodutivas. No tocante à clonagem reprodutiva, o êxito com Dolly teria inaugurado a "era do controle biológico" nas palavras de Ian Willmut, o seu criador. O nascimento da ovelha conferiria poderes de recriar (re-author) a biologia (Franklin, 2001, p. 5). No século XX, natureza passa cada vez mais a significar biologia (Strathern, 1992, p. 15). Na simbólica de parentesco dominante no Ocidente moderno, os laços de sangue, ou genéticos, seriam considerados inexoráveis justamente por pertencer à ordem da Natureza, e não à ordem da lei (Schneider, 1968). Na medida em que cientistas se propõem a ser autores, recriadores da biologia ou da natureza, que a técnica permite redesenhá-la, é possível considerá-la como ordem moral?

\section{Conclusão}

A concepção que toma a biologia ou a genética como a essência da natureza humana permeia os depoimentos e discursos aqui analisados. Pode-se reconstituir a origem de tal concepção no desenvolvimento das idéias do Ocidente Moderno. Critérios fisicalistas para afirmar essa natureza são informados pela ideologia universalista, da qual o cientificismo é aspecto integrante (Duarte, 2004). Atributos físicos seriam naturais, considerados, portanto, universais segundo a cosmologia surgida no Iluminismo, em que a biologia é vista como a base material do epifenômeno social (Laqueur, 1992). Segundo Le Breton (1995), no individualismo ocidental moderno, herdeiro de dualismos que opõem corpo e alma, existe uma ambigüidade entre ser e ter um corpo. Há uma tendência marcante nos saberes biomédicos de se perceber esse corpo cada vez mais como uma realidade física que subsume outro plano como a mente, o espírito ou a cultura. A análise de Dumit (1997) exemplifica essa redução da idéia de mente ao funcionamento do cérebro representado fisicamente no exame de PET scanning. Viveiros de Castro (1996, p. 138 n. 
19) comenta que, estando excluída a dimensão de sobrenatureza da cosmologia ocidental, o modo de universalizar o espírito é identificálo à estrutura e funcionamento do cérebro. Identifica-se o universal com o natural, isto é, o físico. Este tipo de representação relaciona-se ao traço evolucionista da cosmologia ocidental, que diferencia o ser humano do animal (Viveiros de Castro, 1996).

A mudança epistêmica ocorrida por ocasião do Iluminismo em que a natureza passa a ser considerada fundamento da realidade está na origem dessas concepções que tomam a biologia como a realidade. $\mathrm{O}$ antropólogo Tim Ingold, em artigo propondo-se a abrir diálogo entre antropologia e biologia, diz buscar a realidade da pessoa, não a sua representação (Ingold, 1990, p. 220, grifo no original). Ingold (1991) descreve como característica do discurso ocidental seu fundamento ontológico na separação entre um mundo interno de mente e sentido e um externo de matéria e substância. A criança é desde o início biologicamente um ser humano, mas precisa elevar-se da condição de organismo pelo processo de socialização, para tornar-se pessoa.

Constatou-se a biologização da identidade de parentesco. $\mathrm{Na}$ impossibilidade de se obter o parentesco genético com a contribuição dos gametas das pessoas que planejaram ter o filho, o recurso aos doadores passa por critérios de semelhança física e mais especificamente biológica. A fim de se mimetizar o parentesco genético, o cuidado na seleção de doadores leva em conta a origem racial do doador, cor e textura de cabelos, cor da pele e dos olhos, mas também o tipo sangüíneo e outras características imunológicas, além de dados de saúde. A caracterização do doador abrange aspectos sociais com informações sobre profissão, nível de instrução e religião. Pode-se falar de naturalização de traços sociais.

O desenvolvimento técnico implica desdobramentos no parentesco. A genetização do parentesco diz respeito à representação dos laços de parentesco como relações genéticas, sendo considerada a base verdadeira para a constituição tanto do parentesco, como da identidade pessoal e de suas origens. Há uma tensão entre práticas que constroem o parentesco enquanto fruto da escolha e intenção, como a adoção, a doação de gametas e a gestação substituta, e o desenvolvimento de técnicas como a ICSI, como meios de efetivar o parentesco genético, isto é, "verdadeiro". Os exames de DNA podem favorecer esse "realismo genético" do parentesco, mas a pesquisa etnográfica sugere que as motivações dos envolvidos vão além do conhecimento da identidade e de origens, implicando o restabelecimento ou ruptura de relações de casal, o sustento dos filhos, o fim de desconfianças quanto à legitimidade, o reatamento de relações entre pais e filhos.

A motivação principal para o uso das técnicas de reprodução assistida encontrada entre as informantes consiste em efetivar o paren- 
tesco como comunhão de substância biológica ou genética. De modo geral houve superposição entre a noção tradicional de parentesco de sangue e a noção científica moderna de parentesco genético com o DNA. A transmissão de características não só físicas, mas também sociais está no centro dessas preocupações. A intenção é usar as técnicas para propiciar o parentesco de sangue geralmente identificado com os genes, mas também com a gestação. Sangue às vezes se aproxima do discurso biomédico e se torna DNA. O sangue garante a semelhança física e de caráter entre pais e filhos. ${ }^{18}$ Assim, é possível identificar um sistema comum de símbolos e representações de parentesco em que as pessoas são definidas relacionalmente a partir de seus laços de sangue, sangue este percebido como uma herança que envolve tanto o lado biogenético como a tradição de família. Essa noção difere de uma visão biologizante de hereditariedade apresentada por certos segmentos da área de biomedicina, em que o comportamento social está inscrito nos genes. Pode haver uma origem comum, e mesmo comunicação com intercâmbio de significantes como o teste de DNA entre essas duas visões de 'herança', mas uma não se reduz à outra.

Se, nos modelos populares de parentesco, há certa convergência entre sangue e DNA ou genes, nos modelos eruditos oriundos ou fundamentados nas ciências biomédicas, como é o caso do direito, há uma hierarquização, em que o parentesco genético é prioritário em contraposição aos laços criados na gestação. Isso é patente na exigência de anonimato no caso da doação de gametas, como se o laço genético fosse crucial, enquanto se exige parentesco e proximidade entre a gestante substituta e a mulher em favor de quem a primeira gestará o bebê. Os participantes dessa circulação de substâncias germinativas se vêem diante de diversas escolhas: abrir mão do filho gestado? Abrir mão da contribuição genética doada? Aceitar a transmissão hereditária de outro casal, na gestação de um embrião doado? Reconhecer como seu o filho gestado em ventre alheio, ou de outra que não sua esposa? Reconhecer como seu o filho que não tem sua herança genética? Como na adoção, as dimensões de escolha do parentesco - socialmente construídas - são explícitas, no entanto, ao contrário da adoção, se inclui a escolha do material biológico alheio para formar a própria prole na reprodução assistida com a participação de terceiros doadores.

É possível falar de parentesco ou geração natural no contexto das novas tecnologias reprodutivas? Já se mencionou a tendência a biologizar e genetizar a identidade de parentesco. Usam-se 'dados da natureza' para fundamentar argumentos baseados em crenças anteriores ao desenvolvimento da ciência biologia. Outras vezes, pode-se invocar o mesmo dado biológico para fundamentar posições diferentes: gestação e parto devem ser considerados relevantes ou não para designar a maternidade? Isso depende se a situação é de gesta- 
* Este artigo é uma versão abreviada da comunicação "Natureza Humana Criada em Laboratório: Biologização da Pessoa, Genetização do Parentesco e Eugenia nas Novas Tecnologias Reprodutivas", apresentada no XXVIII Encontro da Anpocs, Caxambu, 2004. ção substituta ou de doação de óvulos. Que dado biológico conta, afinal? O uso do referente biológico como fundamento de verdade é o valor que se mantém continuamente nesse debate para estabelecer a definição legítima de natureza humana.

É difícil estabelecer limites entre o natural e o cultural em um campo em que a biologia é continuamente afetada pela intervenção técnica. Natureza assistida deixa de ser natural? As tecnologias de procriação, ao ampliarem o leque de escolhas na área de parentesco, enfatizariam o seu caráter intencional. Porém, mesmo escolhas que aparentemente contrariem a natureza, como a busca de sêmen de doador de gametas para que um casal lésbico procrie, podem ser feitas segundo uma lógica que toma o parentesco natural como referência: ao privilegiar a gravidez e não a adoção como meio de ter filhos, ao solicitar que o óvulo de uma companheira seja transferido para o útero da outra, a fim de que ambas sejam "mães biológicas", uma pela gestação e outra pela dotação genética.

Qual o significado de natureza humana produzida no contexto do laboratório? Independentemente da intervenção técnica inovadora, os mesmos valores que norteiam a concepção ocidental moderna de ser humano, o indivíduo, informam a compreensão da biologia: autonomia, individualidade, escolha. Considera-se natureza biológica humana como característica geral da espécie e, ao mesmo tempo, característica particular do indivíduo autônomo. A noção de natureza como fundamento da realidade e ordem moral é relativizada diante da plasticidade na construção da natureza humana em laboratório.

\section{NOTAS}

1 "Indeed, on closer inspection, the very notion of 'genetic relationship' may be seen to be perfectly absurd. For genetic kinship refers, and can only refer to those attributional affinities that are present among individuals by virtue of their endogenous constitution prior to their entering into any relationships at all ... In short, genetics has to do with (quantitative) coefficients of relatedness, not with the (qualitative) dynamics of relationship..." (Ingold, 1991, p. 361). Quanto aos coeficientes quantitativos de parentesco, estes já estavam presentes no antigo modelo do sangue, segundo o qual a pessoa tinha metade do sangue do pai ou da mãe, um quarto de cada avô, um oitavo de cada bisavô (Duhn \& Dobzhansky, 1956).

2 Enquanto a noção de "sangue" é um operador simbólico que conecta os sujeitos (parentes consangüíneos), a ênfase em fatos naturais da embriologia como fundamento da pessoa desconecta e oculta relações (Salem, 1997, p. 84 ss). A interpretação do DNA como elemento fundante do indivíduo constituído na forma de mônada é um modo dessa visão não-relacional.

3 Conferir os casos relatados por Price (1999, p. 46 ss). Cussins (1998) relata casos de doação não-comercial de óvulos nos Estados Unidos, em que se apresenta uma amiga de mesmo grupo étnico (ítalo-americana, negra), e outros, em que a filha doa óvulos para a mãe no segundo casamento, ou em favor de sua mãe para a gestante substituta, em ambos os casos com sêmen do companheiro da mãe intencional.

${ }^{4} \mathrm{O}$ direito dos filhos adotivos de conhecer a identidade de seus "pais biológicos" ao chegar à maioridade influiu no debate sobre o anonimato do doador de gametas na Inglaterra e na Suécia (Leite, 1995). Um dos projetos de lei sobre reprodução assistida em tramitação no Congresso Nacional traz essa sugestão (Diniz, 2003).

${ }^{5} \mathrm{O}$ único exemplo semelhante é a sugestão de transplante de testículos entre homens parentes de primeiro grau a fim de manter a continuidade genética da família em caso de infertilidade masculina (Luna, 2002a). 
6 Agradeço a Fernanda Eugênio pela informação sobre seu trabalho de campo.

7 Encontram-se exemplos dessa prática nos Estados Unidos em notícias da grande imprensa (cf. Luna, 2002b).

8 Palestra "Manipulação genética e reprodução assistida", proferida pelo dr. Roger Abdelmassih em 23 de setembro de 2002 no Instituto dos Advogados de São Paulo, no ciclo "Biodireito e Manipulações Genéticas".

${ }^{9}$ Mantendo uma expressão oriunda dos processos de adoção no Direito que dissocia a parentalidade biológica e a sócio-afetiva (Leite, 1995), os médicos chamam a mãe intencional que contribui com o óvulo de "mãe biológica", como se a gestação não estabelecesse relação biológica entre a gestante e o feto, tese de diversos informantes. Essa negação do laço biológico estabelecido pela gestação aponta para a redução do biológico ao genético (Strathern, 1998), constituindo um dos aspectos da genetização do parentesco (Strathern, 1992).

10 Leite (1995) fala do procedimento francês de adoção da criança pela "mulher de seu pai" no contexto de inseminação artificial (a mãe substituta é também a mãe genética da criança). A fim de evitar a presunção de sua paternidade, o marido de uma gestante substituta deve participar do contrato do consentimento informado, prometendo abster-se de relações sexuais com a esposa durante o período de tratamento até a gravidez ser confirmada pelo médico (Ragoné, 1994). Strathern (1991) fala de emendas na lei inglesa para contornar o procedimento de o casal ter que adotar a criança quando um deles ou ambos contribuíram com os gametas, de modo que ambos fossem tratados na lei como pais.

11 Provavelmente interpretou-se a regra do CFM no sentido de que os parentes consangüíneos e os por afinidade pertençam à família da doadora genética.

12 Talvez o fato de a gestante substituta ser a irmã do pai genético da criança tenha influído na postura do casal, de buscar o registro direto dos pais genéticos.

13 A descrição da doação compartilhada foi obtida na comunicação "Óvulo: doação altruística ou compartilhada?" do Dr. Joaquim Costa, proferida na mesa redonda "Controvérsias" do VI Congresso da Sociedade Brasileira de Reprodução Assistida.

14 Strathern (1992, p. 151-8) fala da fragmentação do papel materno no contexto ocidental. A biomedicina produz a fragmentação do corpo.

15 Trata-se de um exemplo de doação compartilhada.

16 Essa exclusão sugere a inexistência de clientela negra ou com ascendentes negros nas clínicas particulares de reprodução assistida. Costa (2003) registra relatos de pouca demanda por doadores negros nos bancos de sêmen.

17 Cf. comunicação "Aspectos genéticos atuais", apresentada pelo Dr. Edson Borges Júnior na mesa redonda "Infertilidade masculina" em 26.9.2002 durante o VI Congresso Brasileiro de Reprodução Assistida. O autor avaliou que o risco seria inerente à qualidade do espermatozóide e não à técnica em si.

18 O "sangue", como "a configuração dos nervos" analisada por Duarte (cf. 1986), relaciona-se ao plano físicomoral.

\section{REFERÊNCIAS BIBLIOGRÁFICAS}

Abreu Filho, Ovídio de Parentesco e identidade social. Anuário Antropológico/80. 1982 Fortaleza: Universidade Federal do Ceará, Rio de Janeiro: Tempo Brasileiro. p. 95-118.

Aragão, Luiz Tarlei 1983

Em nome da mãe: posição estrutural e disposições sociais que envolvem a categoria mãe na civilização mediterrânea e na sociedade brasileira. In: Perspectivas antropológicas da mulher 3. Rio de Janeiro: Zahar. p. 109-45.

Bourdieu, Pierre 1996

A economia das trocas lingüísticas: o que falar quer dizer. São Paulo: Edusp.

Carrara, Sérgio 1996

Tributo a Vênus: a luta contra a sífilis no Brasil, da passagem do século aos anos 40. Rio de Janeiro: Fiocruz.

1995

Conselho Federal de Medicina.

Resolução n. 1358/92 do CFM. Em: Leite, Eduardo Oliveira. Procriações artificiais e o direito: aspectos médicos, religiosos, psicológicos, éticos e jurídicos. São Paulo: Ed. Revista dos Tribunais. p. 429-32. 
Corrêa, Marilena V. 2000

Costa, Rosely Gomes 2003

Cussins, Charis $M$. 1998

Diniz, Débora nov.-dez. 2003

Duarte, Luiz

Fernando Dias 2004

Duarte, Luiz

Fernando Dias 1986

Dumit, Joseph 1997

Dunn, L. C.;

Dobzhansky, T. 1956

Edwards, Jeanette 1999

Finkler, Kaja Apr. 2001

Fonseca, Claudia 2003

Fonseca, Claudia 2002

Franklin, Sarah Jun. 2001

Franklin, Sarah 1999

Hayden, Corinne P. 1995

Hirsch, Eric 1999
Novas tecnologias reprodutivas: doação de óvulos. O que pode ser novo nesse campo? Cadernos de saúde pública, v. 16, n. 3, p. 863-70.

Tecnologias reprodutivas e noções sobre racialização e etnia. Comunicação apresentada no XXVII Encontro Anual da Anpocs, Caxambu (MG). (Mimeogr.)

Quit sniveling, cryo-baby. We'll work out which one's your mama. In: Davies-Floyd, Robbie; Dumit, Joseph (ed.) Cyborg babies: from technosex to techno-tots. New York: Routledge. p. 40-67.

Tecnologias reprodutivas conceptivas: o estado da arte do debate legislativo brasileiro. Jornal brasileiro de reprodução assistida, v. 7, n. 3, p. 10-9.

A pulsão romântica e as ciências humanas no Ocidente. Revista brasileira de ciências sociais, v. 19, n. 55, p. 5-18.

Da vida nervosa nas classes trabalhadoras urbanas.

Rio de Janeiro: Jorge Zahar.

A digital image of the category of the person: PET scanning and objective self-fashioning. In: Downey, G. L.; Dumit, J. Cyborgs and citadels: anthropological interventions in emerging sciences and technologies. Santa Fe (New Mexico): School of American Research Press.

Herencia, raza y sociedad.

México/Buenos Aires: Fondo de Cultura Económica.

Explicit connections: ethnographic enquiry in northwest England. In: Edwards, J. et al. Technologies of procreation: kinship in the age of assisted conception. 2. ed. London/New York: Routledge. p. 60-85.

The kin in the gene: the medicalization of family and kinship in American society. Current Anthropology, v. 42, n. 2, p. 235-63.

Paternidade e DNA: a certeza que pariu a dúvida.

II Seminário internacional/ I Seminário Norte-Nordeste Homens, sexualidade e reprodução: tempos, práticas e vozes. Comunicação apresentada na mesa redonda 'Sexualidade, masculinidade e reprodução'. Recife, 17 a 20 de junho. (Mimeogr.)

A vingança de Capitu: DNA, escolha e destino na família brasileira contemporânea. In: Bruschini, Cristina; Unbehaum, Sandra G. (org.) Gênero, democracia e sociedade brasileira. São Paulo:

Fundação Carlos Chagas, Ed. 34. p. 267-95.

Sheepwatching.

Anthropology today, v. 17. n. 3, p. 3-9.

Making representations: the parliamentary debate on the Human Fertilization and Embryology Act. In: Edwards, J. et al. Technologies of procreation: kinship in the age of assisted conception.

2. ed. London/New York: Routledge. p. 127-69

Gender, genetics and generation: Reformulating biology in lesbian kinship. Cultural anthropology, v. 10, n. 1, p. 41-63.

Negotiated limits: interviews in south-east England. In: Edwards, J. et al. Technologies of procreation: kinship in the age of assisted conception.

2. ed. London/New York: Routledge. p. 91-121. 
Ingold, Tim 1991

Ingold, Tim jun. 1990

Laqueur, Thomas 1992

Le Breton, David 1995

Lenoble, Robert 1990

Leite, Eduardo Oliveira 2000

Leite, Eduardo Oliveira 1995

Luna, Naara 2004

Luna, Naara 2002a

Luna, Naara 2002b

Pagels, Elaine 1989

Price, Frances 1999

Ragoné, Helena 1994

Sahlins, Marshall 1976

Salem, Tania 1997

Salem, Tania 1995

Schneider, David 1968

Strathern, Marilyn 1999

Strathern, Marilyn 1998

Strathern, Marilyn 1995a
Becoming persons: consciousness and sociality in human evolution. Cultural dynamics, v. 4, n. 3, p. 355-78.

An anthropologist looks at biology.

Man (N.S.), v. 25, n. 2, p. 208-29.

Making sex: body and gender from the greeks to Freud.

Cambridge/London: Harvard University Press.

Anthropologie du corps et modernité.

3. ed. Paris: Presses Universitaires de France.

História da idéia de natureza.

Lisboa: Ed. 70.

Exame de DNA, ou o limite entre o genitor e o pai. In: Leite, E. O. (coord.) Grandes temas da atualidade: DNA como meio de prova da filiação.

Rio de Janeiro: Forense. p. 61-85.

Procriações artificiais e o direito: aspectos médicos, religiosos, psicológicos, éticos e jurídicos. São Paulo: Ed. Revista dos Tribunais.

Provetas e clones: teorias da concepção, pessoa e parentesco nas novas tecnologias reprodutivas. Tese de doutoramento. Programa de PósGraduação em Antropologia Social, Museu Nacional, UFRJ. (Mimeogr.)

Parentesco com ou sem gene: um inventário do desenvolvimento recente das novas tecnologias reprodutivas. XXIII Reunião Brasileira de Antropologia, fórum de pesquisa 'Corpo, doença e sexualidade'. Gramado, junho.

Maternidade desnaturada: uma análise da barriga de aluguel e da doação de óvulos. Cadernos Pagu, v. 19, p. 233-78.

Adam, Eve and the serpent.

New York: Vintage Books.

Clinical practices and clinical concerns. In: Edwards, J. et al.

Technologies of procreation: kinship in the age of assisted conception.

2. ed. London/New York: Routledge. p. 29-59.

Surrogate motherhood: conception in the heart.

Boulder, San Francisco \& Oxford: Westview Press.

The use and abuse of biology: an anthropological critique of sociobiology. University of Michigan.

As novas tecnologias reprodutivas: o estatuto do embrião e a noção de pessoa. Mana, v. 3, n. 1, p. 75-94.

O princípio do anonimato na inseminação artificial com doador (IAD). Physis - Revista de Saúde Coletiva, v. 5, n. 1, p. 33-68.

American kinship: a cultural account.

New Jersey: Prentice-Hall.

Regulation, substitution and possibility. In: Edwards, J. et al. Technologies of procreation: kinship in the age of assisted conception.

2. ed. London/New York: Routledge. p. 171-216.

Surrogates and substitutes: new practices for old? In: Good, James;

Velody, Irving (ed.) The Politics of postmodernity.

Cambridge University Press. p. 182-209.

Necessidade de pais, necessidade de mães.

Estudos Feministas, Rio de Janeiro, v. 3, n. 2, p. 303-29. 
Strathern, Marilyn 1995b

Strathern, Marilyn 1992

Strathern, Marilyn 1991

Tamanini, Marlene 2003

Viveiros de Castro, Eduardo

1996
Displacing knowledge: technology and the consequences for kinship. In: Ginsburg, Faye G.; Rapp, Rayna (ed.) Conceiving the new world order. Berkeley/Los Angeles/London: University of California Press. p. 323-45.

Reproducing the future: essays on anthropology, kinship and the new reproductive technologies. Manchester: Manchester University Press.

Disparities of embodiment: gender models in the context of the new reproductive technologies. Cambridge anthropology, v. 15, n. 2, p. 25-43.

Novas tecnologias reprodutivas conceptivas à luz da bioética e das teorias de gênero: casais e médic@s no Sul do Brasil.

Tese de doutoramento, PPGICH, UFSC. (Mimeogr.)

Os pronomes cosmológicos e o perspectivismo ameríndio.

Mana, v. 2, n. 2, p. 115-44.

Recebido para publicação em novembro de 2004.

Aprovado para publicação em maio de 2005. 